\title{
点眼薬含有塩化ベンザルコニウムの角膜上皮に対する影響
}

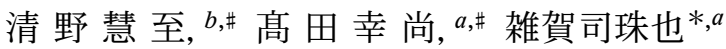

\section{Effects of Benzalkonium Chloride in Ophthalmic Eyedrop Medications on Corneal Epithelium}

\author{
Satoshi Seino, ${ }^{b, \#}$ Yukihisa Takada, ${ }^{a, \#}$ and Shizuya Saika ${ }^{*, a}$ \\ aDepartment of Ophthalmology, Wakayama Medical University; 811-1 Kimiidera, Wakayama 641-8509, Japan: \\ and ${ }^{b} R \& D$ Division, Kewpie Corporation; 2-5-7 Sengawa-cho, Chofu, Tokyo 182-0002, Japan.
}

(Received August 16, 2020)

\begin{abstract}
Eyedrops often contain additives other than active pharmaceutical ingredients, such as preservatives. The most frequently used preservative is benzalkonium chloride (BAC). When the ocular surface is exposed to eyedrops, the active pharmaceutical ingredients and additives can cause corneal epithelial disorder. Particularly in clinical settings, there is great interest in corneal epithelial disorders resulting from the use of glaucoma eyedrops, which is inevitable when instilled for a long period of time after the onset of disease. At the authors' institute, glaucoma is treated with consideration of reducing corneal epithelial disorder while ensuring the effect of lowering intraocular pressure by the appropriate choice of eyedrops. In this review, we show the examples of the retrospective studies. Sodium hyaluronate eyedrops are prescribed for corneal epithelial disorders such as superficial punctate keratitis associated with dry eye. Prescribable concentrations of sodium hyaluronate in Japan are $0.1 \%$ or $0.3 \%$, and the $0.3 \%$ formulation does not contain BAC. The authors' study showed that $0.3 \%$ sodium hyaluronate pretreatment reduced the cytotoxicity of BAC in cultured corneal epithelial cells, whereas an in vivo study in mice showed that a $0.3 \%$ sodium hyaluronate instillation was suggested and that the drug may enhance the cytotoxicity of separately administered BAC. It is suggested that sodium hyaluronate prolonged the retention of BAC on the ocular surface. However, there have been no reports of this problem in the clinical setting. It is important for ophthalmologists to understand the properties of additives other than the active pharmaceutical ingredients in eyedrops.
\end{abstract}

Key words - eyedrop; benzalkonium chloride; glaucoma; dry eye; drug-induced corneal epithelial disorder

\section{はじめに}

点眼薬は薬効を示す主薬のほか, 種々の添加物が 含まれている．眼表面への刺激を和らげ使用感を改 善する $\mathrm{pH}$ 調整剤, 緩衝剤や等張化剂, 薬剤として の品質を保持する可溶化剂，安定化剂や防腐剤，主 薬の眼表面における滞留性を上昇させる粘稠化剂な どが挙げられる，繰り返し投与する点眼薬では，防 腐剤による微生物污染の防止が必要となる。最も頻 繁に使用される防腐剂は塩化ベンザルコニウム (benzalkonium chloride; BAC) である. BAC は四 級アンモニウムカチオン化合物で，相溶性や抗菌ス

$a$ 和歌山県立医科大学医学部眼科（₹641-8509 和歌山 市紀三井寺 811-1), ${ }^{b}$ キユーピー株式会社研究開発本 部（广182-0002 東京都調布市仙川町 2-5-7）

*e-mail: shizuya@wakayama-med.ac.jp

本総説は, 日本薬学会第 140 年会シンポジウム S02 で 発表した内容を中心に記述したものである.

${ }^{\#}$ These authors contributed equally to this work.
ペクトルに優れるといった特長を有する. 一方で, 使用する濃度や頻度によっては角膜上皮障害を誘発 する. ${ }^{1)}$ 本稿では BACによる角膜上皮障害を軽減 するために臨床及び基礎実験で検討した内容を紹介 する．臨床では，BACの有無や薬剤の違いが角膜 上皮にどのような影響を及ぼすか，種々の緑内障点 眼薬について比較した。基礎実験では，BAC 含有 点眼薬とヒアルロン酸ナトリウム点眼薬を併用した 際の影響について評価した。

\section{1. 臨床における塩化ベンザルコニウムと角膜上} 皮障害

1-1. 緑内障点眼薬と角膜上皮障害 緑内障は 進行性で不可逆的な疾患であり, 長期に渡る治療が 必要な疾患である。 40 歳以上で有病率約 $5 \%$ と言わ れており，中途失明の原因疾患で第一位となってい る。唯一エビデンスのある治療は眼圧下降であ る. ${ }^{2,3)}$ 治療は主に点眼薬治療と手術治療である。ど 
A

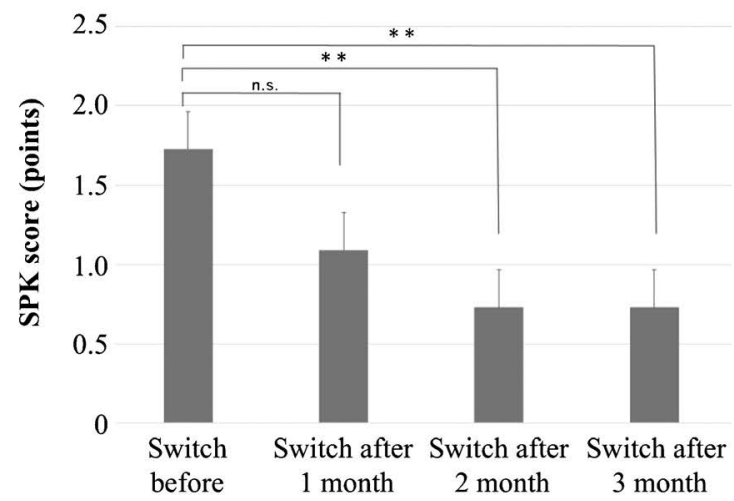

B

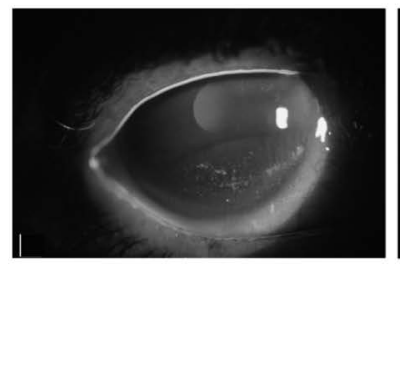

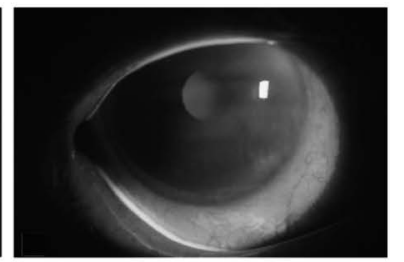

Fig. 1. Changes in Corneal Epithelial Disorders Associated with Switching Eyedrops

(A) Changes in SPK score after switching from Tapros ${ }^{\circledR \mathbb{B}}$ to Tapros mini ${ }^{\circledR}$. The vertical axis indicates SPK score (points). The horizontal axis indicates before and 1,2 , and 3 months after switching eyedrops. n.s., not significant; ${ }^{* *} p<0.01$. (B) Representative image of fluorescein stained cornea with slit-lamp biomicroscopy. Left panel, before switching from Tapros ${ }^{\circledR}$. Right panel, 3 months after switching to Tapros mini ${ }^{\circledR}$. Partially modified from Ganka, 61 (8), 863-867 and reprinted with permission by Kanehara and Co. Ltd.

の緑内障病期であっても，点眼薬治療をまずは行う こととなる.

昨今では前視野緑内障の概念が広がり，緑内障点 眼開始の時期は以前に比べて早まっており, 平均寿 命の高齢化とあわせて，一生涯において緑内障の点 眼治療期間は伸びる傾向にあると思われる.

臨床の現場では眼圧下降効果の高いプロスタグラ ンジン（prostaglandin; PG）製剤が第一選択とな ることが多い，PG 製剤が販売される以前は $\beta$ 遮断 薬が選択されることが多かつたが，現在でも $\mathrm{PG}$ 製 剤を使用できない症例や併用薬として処方頻度は多 い.

PG 製剂, $\beta$ 遮断薬には様々な副作用があること が知られており，PG 製剤では色素沈着, ${ }^{4)}$ 上眼瞼 溝深化, 5) 角膜上皮障害6)などが副作用として代表 的である. $\beta$ 遮断薬では全身副作用として呼吸器異 常7) - 循環器異常, 8) 眼局所の副作用として角膜知 覚神経障害, 角膜障害が知られている. ${ }^{9}$

$\mathrm{PG}$ 製剤, $\beta$ 遮断薬に共通して, 副作用として角 膜上皮障害が挙げられる，角膜上皮障害の原因とし て防腐剤である BACについて多数報告がされてき たが, 1,10,11) 主薬による影響についても報告があ り, ${ }^{12)}$ 今後は主薬とBAC の相互作用について, 追 加検討が必要と考える.

また，緑内障治療において，1 剂で目標眼圧を達 成できなければ， 2 剂以上の複数系統の点眼薬の使 用が必要となる。しかし，緑内障点眼薬の点眼回数 や点眼薬数の増加は角膜上皮障害の頻度や重症化と
関連があることが知られている. ${ }^{13)}$ 緑内障を新規で 診断されてから 1 年の間に約 $40 \%$ は治療を継続で きていないことが報告されており,14)継続した緑内 障治療を可能とするためにも角膜上皮障害を始めと する副作用の軽減は重要な課題である.

1-2. 緑内障点眼薬による治療の最適化 $\quad P G$ 製剂による角膜上皮障害を軽減するには，BAC か ら他の防腐剂へ変更することで角膜上皮障害が軽減 することや, 15,16) 同一主薬で BAC を含まない製品 へ変更することによって角膜上皮障害が軽減するこ とが知られている. ${ }^{17)}$ 緑内障点眼薬として主たる効 果である眼圧下降効果を維持したうえで，角膜上皮 障害を軽減するために先発品, 後発品ともにBAC 非含有の製品が開発されてきた.

筆者らは，同一主薬の $\mathrm{PG}$ 製凨（タプロス ${ }^{\circledR}$ ，参 天製薬，大阪）から $\mathrm{BAC}$ 非含有単回使用 $\mathrm{PG}$ 製剤 （タプロスミニ ${ }^{\circledR}$ ，参天製薬，大阪）へ変更した際の 眼圧と角膜上皮障害の変化について報告した。 ${ }^{17)}$ 夕 プロス ${ }^{\circledR}$ 使用中の緑内障症例で角膜上皮障害を伴う 14 例 14 眼で，タプロスミニ ${ }^{\circledR} に$ 変更したところ, 涙液層破壊時間（tear film break-up time; BUT）や 涙液量の有意な変化はみられなかったが，ドライア イ研究会の基準を基に角膜上皮障害のスコアリング を行った点状表層角膜症（superficial punctate keratopathy； SPK）スコアが 2 カ月目以降で有意に改 善した（点眼変更前 $1.71 \pm 0.73$ 点：点眼変更 2 力 月後：0.71 \pm 0.61 点） [Fig. $1(\mathrm{~A})]$ 。代表症例を Fig. 1(B) に示す。このことから，BAC 非含有単回 
A

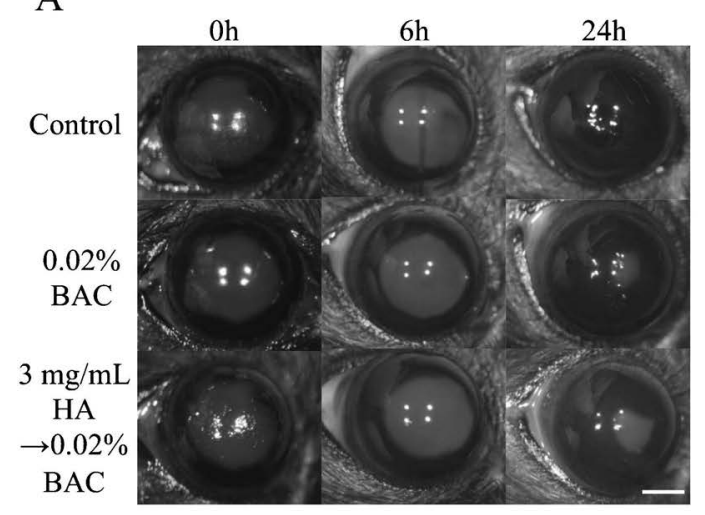

$\mathrm{C}$

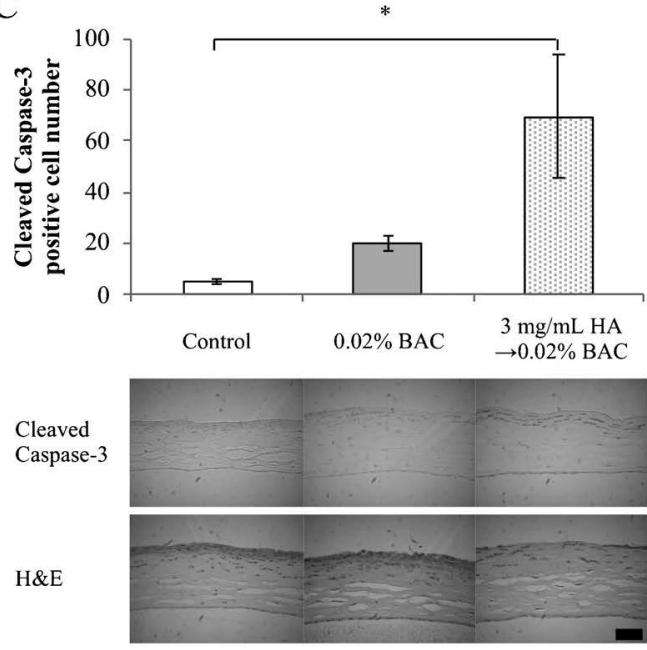

B

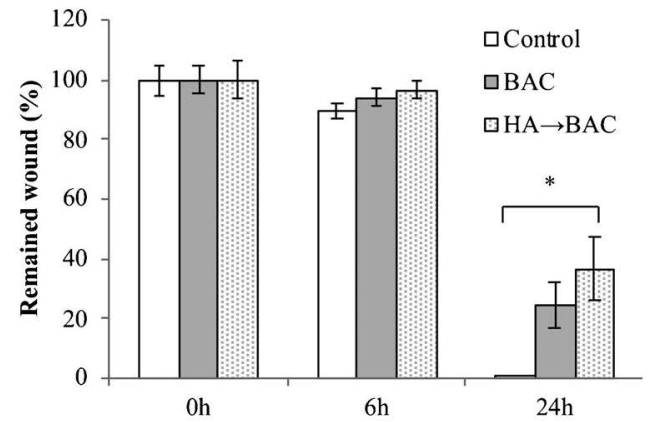

$\mathrm{D}$

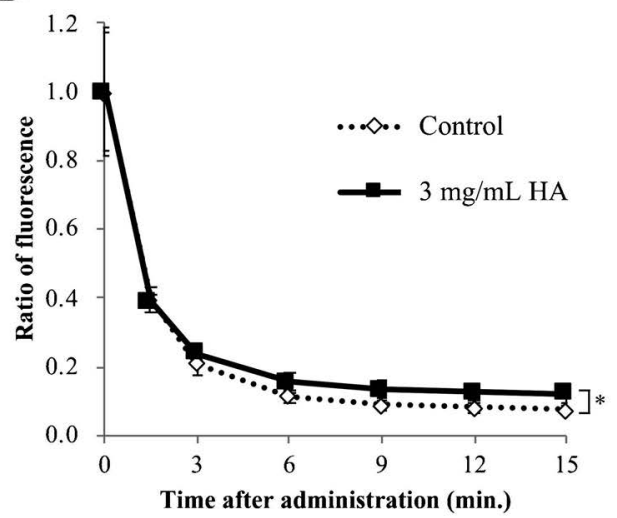

Fig. 2. Effects of HA and BAC on Corneal Epithelial Wound Healing in C57BL/6J Mouse

Effects of HA and BAC on corneal epithelial wound healing in mice were evaluated. (A, B) PBS (-) alone, BAC, or HA and BAC was instilled into the mouse $(n=7)$. Data are expressed as mean \pm S.E., ${ }^{*} p<0.05$. Scale bar, $1 \mathrm{~mm}$. (C) Histological analysis of mouse cornea. Cleaved caspase-3 was stained with immunohistochemistry and positive cells were counted. Hematoxylin and eosin staining (H\&E) was also performed as reference. Data are expressed as mean \pm S.E. $(n=$ 3), ${ }^{*} p<0.05$. Scale bar, $50 \mu \mathrm{m}$. (D) Effects of HA on retention of eyedrops in the ocular surface. HA or PBS eyedrops with fluorescein were administered to the mouse eyes. Fluorescence in the ocular surface was sequentially quantified with IVIS. Data are expressed as mean \pm S.E. $(n=6)$, ${ }^{*} p<0.05$. Partially modified from Cutan. Ocul. Toxicol., 39(1), 13-20 and reprinted with permission by Taylor \& Francis Group.

使用 PG 製剂のタプロスミニは同一主薬の BAC 含有 $\mathrm{PG}$ 製剂のタプロスからの変更により, タプ ロス使用時に角膜上皮障害をみとめる症例におい て眼圧下降効果を維持したまま, 角膜上皮障害軽減 が期待できることが示唆され, 緑内障点眼薬治療を 開始前からドライアイがある症例に対しても,

BAC 含有単回使用 $\mathrm{PG}$ 製剂は有用な選択肢となり 得ると考える.

今日では眼科領域で様々な後発医薬品が販売され ているが, 2010 年に PG 製剤初の後発医薬品が販 売された。 キサラタン ${ }^{\circledR}$ (ファイザー, 東京）の後 発医薬品が 2010 年 10 月当時, 22 社 22 製品が販売 されたが, 先発品のキサラタンから後発医薬品へ の変更により, 角膜上皮障害をみとめた症例を筆者

\section{らは以前に報告した. ${ }^{18)}$}

後発医薬品は先発品と主薬は同一であるが，その 他の添加剤が異なる可能性はある，先述の筆者らの 報告例から先発品と後発医薬品について留意すべき 点を述べる. ラタノプロスト ${ }^{\circledR}$ 点眼薬（科研製薬, 東京）には，先発医薬品のキサラタン®含まれな いモノステアリン酸ポリエチレングリコールとステ アリン酸ポリオシルが含まれていた。 また, 防腐剤 はキサラタン®同様にBACであるが，濃度は非 公開であり同一とは限らなかった。 キサラタンか らの後発医薬品への変更で角膜上皮障害をみとめた 原因物質の特定は困難ではあるが， BAC 濃度や添 加物が異なることが角膜上皮障害の原因となってい る可能性が示唆された.このことから，処方医師は 
先発品と後発医薬品との主薬の効果が同等であって も，予期せぬ合併症が生じる可能性を念頭に入れて 診療にあたる必要があると考える.

\section{2. 基礎実験における塩化ベンザルコニウムと角} 膜上皮障害

2-1. 角膜上皮障害とヒアルロン酸ナトリウム 角膜では上皮が障害されると，まず速やかに周囲 の上皮細胞が遊走し，障害部位を覆う. ${ }^{19)}$ その後, 細胞の分裂と分化を経て重層扁平上皮が再生する. 角膜上皮の創傷治癒が遅延すると, 感染リスクの増 加や露出した角膜実質の融解や角膜穿孔を引き起こ し，視機能を重篤に低下させる。したがって，角膜 上皮の創傷は速やかに治癒する必要がある.

ヒアルロン酸ナトリウム（HA）は多糖類の一種 で，その溶液は粘弾性及び保水性に優れる。 また, 生物学的機能として創傷治癒促進作用を示すことか ら，HA は点眼薬の原薬としてドライアイ及びそれ に伴う角膜上皮障害の治療目的で活用される。 ${ }^{20)}$ $\mathrm{HA}$ 点眼薬は濃度が $0.1 \%$ と $0.3 \%$ が処方可能で, $0.3 \%$ BACが含まれていない.

2-2. ヒアルロン酸ナトリウムと塩化ベンザルコ ニウムを組み合わせた場合の効果 $\mathrm{HA}$ 点眼が $\mathrm{BAC}$ による角膜上皮障害を軽減することが，モデ ル動物を用いた研究で報告されている. ${ }^{21)}$ 一方, 点 眼薬に粘稠化剂を添加することで，防腐剤である BAC の毒性を強調し, 角膜上皮創傷治癒が遅延す ることが報告されている. ${ }^{22)}$ 粘稠な HA 点眼薬と BAC を含む点眼薬を併用した際の相互関係につい ての報告はない.

筆者らは，HA と BAC の併用が角膜上皮の創傷 治癒にどのように影響するかを報告した. ${ }^{23)}$ まず, HA 単独での作用を評価した. In vitro では角膜上 皮細胞株の HCE-T を用いてスクラッチアッセイを 実施し，細胞遊走に及ぼす影響を評価した。In vivo では C57BL/6J マウスの角膜上皮を円形には く離した角膜上皮創傷治癒モデルを用いた。その結 果， $0.3 \%$ HA はいずれの試験系においても上皮 細胞の遊走を促進し，創傷治癒促進作用を示した。

次に， HA と BAC を組み合わせた場合の作用を評 価した. In vitroでは BACによる細胞遊走遅延が HA により軽減された。一方，in vivoでは BAC 単 独では創傷治癒の遅延が認められなかった一方で, BAC 点眼前に $0.3 \%$ HA を点眼した場合, 創傷
治癒の遅延及び cleaved caspase-3 陽性細胞数の増 加が誘導された（Fig. 2)。この作用は，高粘度の $0.3 \% \mathrm{HA}$ 点眼により後から点眼した BAC が眼表面 に滞留したことによりもたらされたと仮説を立て, HA が点眼薬の滞留性に及ぼす影響を評価した。 C57BL/6J マウスに $0.3 \%$ のA 及びフルオレセイ ンを点眼し, in vivo imaging system を用いて蛍光強 度を経時的に測定した。その結果，0.3\%の HA は 対照の生理的リン酸緩衝液と比較して, 点眼 15 分 後の蛍光強度が有意に高い值を示し, 点眼薬の眼表 面における滞留性を上昇させることが示唆された.

以上のように，HA は BAC と組み合わせて点眼 した場合に, BACの滞留性を上昇させ細胞傷害性 を強調することが示唆された。臨床では複数の点眼 薬を処方する際，一般的に 5 分間の間隔をあけるよ う患者に指導される. ${ }^{24)}$ 今回の試験においても HA と BAC の点眼間隔は 5 分間とした。臨床上で HA が BAC 含有点眼薬の毒性を強調するといつた不具 合の報告はないものの, 粘稠な点眼薬と他の点眼薬 を併用する際は BAC の有無や点眼間隔に留意する 必要があると考える.

\section{おわりに}

本稿ではBACによる角膜上皮障害について，臨 床における緑内障点眼薬の BAC の有無による差異 や，基礎実験でのヒアルロン酸点眼薬との併用によ る影響を紹介した。点眼薬中の BAC は他の防腐剂 による代替若しくは非含有化が試みられているもの の，依然として多くの点眼薬に使用されている. BAC は炭素鎖長により抗菌性や細胞毒性が異なる ことが報告されており, ${ }^{25)}$ 抗菌性の維持と細胞毒性 の軽減の両立が期待される. 点眼薬の主薬の作用の みならず防腐剂や粘稠化剂などの添加物の特性につ いても理解し，処方することが要求される.

利益相反 雑賀司珠也はキユーピー株式会社か ら研究助成金を受領した。清野慧至（キユーピー株 式会社の社員).

\section{REFERENCES}

1) Baudouin C., Labbé A., Liang H., Pauly A., Brignole-Baudouin F., Prog. Retin. Eye Res., 29, 312-334 (2010).

2) Casson R. J., Chidlow G., Wood J. P. M., 
Crowston J. G., Goldberg I., Clin. Exp. Ophthalmol., 40, 341-349 (2012).

3) Anderson D. R., Drance S. M., Schulzer M., Am. J. Ophthalmol., 126, 487-497 (1998).

4) Stjernschantz J. W., Albert D. M., Hu D. N., Drago F., Wistrand P. J., Surv. Ophthalmol., 47, 162-175 (2002).

5) Aihara M., Shirato S., Sakata R., Jpn. J. Ophthalmol., 55, 600-604 (2011).

6) Sudesh S., Cohen E. J., Rapuano C. J., Wilson R. P., Arch. Ophthalmol., 117, 539 (1999).

7) Morales D. R., Dreischulte T., Lipworth B. J., Donnan P. T., Jackson C., Guthrie B., Br. J. Clin. Pharmacol., 82, 814-822 (2016).

8) Munroe W. P., Rindone J. P., Kershner R. M., D’Arcy P. F., Drug Intell. Clin. Pharm., 19, 85-89 (1985).

9) Weissman S. S., Asbell P. A., Br. $J$. Ophthalmol., 74, 409-412 (1990).

10) Liang H., Baudouin C., Daull P., Garrigue J.S., Buggage R., Brignole-Baudouin F., Cornea, 31, 1319-1329 (2012).

11) Xiong C., Chen D., Liu J., Liu B., Li N., Zhou Y., Liang X., Ping M., Ye C., Ge J., Wang Z., Investig. Ophthalmol. Vis. Sci., 49, 1850-1856 (2008).

12) Takada Y., Yamanaka O., Okada Y., Sumioka T., Reinach P. S., Saika S., Cutan. Ocul. Toxicol., 39, 75-82 (2020).

13) Fukuchi T., Wakai K., Suda K., Nakatsue T., Sawada H., Hara H., Ueda J., Tanaka T.,
Yamada A., Abe H., Clin. Ophthalmol., 4, 203-209 (2010).

14 ) Kashiwagi K., Furuya T., Jpn. J. Ophthalmol., 58, 68-74 (2014).

15) Minami Y., Hoshi S., Kondoh E., Iwabe R., Mori K., Journal of the Eye, 29, 1401-1404 (2012).

16) Kim Y. H., Jung J. C., Jung S. Y., Yu S., Lee K. W., Park Y. J., Cornea, 35, 234-242 (2016) .

17) Takada Y., Sumioka T., Saika S., Ganka, 61, 863-867 (2019).

18) Takada Y., Okada Y., Fujita N., Saika S., Case Rep. Ophthalmol. Med., 536746 (2012).

19) Ljubimov A. V., Saghizadeh M., Prog. Retin. Eye Res., 49, 17-45 (2015).

20) Nishida T., Nakamura M., Mishima H., Otori T., Exp. Eye Res., 53, 753-758 (1991).

21) Liu X., Yu F. F., Zhong Y. M., Guo X. X., Mao Z., Chin. Med. J. (Engl.), 128, 24442449 (2015).

22) Nagai N., Ito Y., Okamoto N., Shimomura Y., Yakugaku Zasshi, 132, 837-843 (2012).

23) Seino S., Matsuoka R., Masuda Y., Kunou M., Okada Y., Saika S., Cutan. Ocul. Toxicol., 39, 13-20 (2020).

24) Denion E., Charlot F., Béraud G., Optom. Vis. Sci., 94, 838-844 (2017).

25) Asada H., Takaoka-Shichijo Y., Nakamura M., Kimura A., Yakugaku Zasshi, 130, 867871 (2010). 